\title{
Knowledge of occupational hazards and safety practices among petrol station attendants in Sokoto metropolis, Sokoto State, Nigeria
}

\author{
Okafoagu Nneka C, MBBS; MPH; FWACP ${ }^{1 *}$, Oche Mansur O, MBBS; MPH; FWACP ${ }^{2}$, \\ Gana Godwin J, MBBS; FWACP ${ }^{1}$, Ango Jessica T, MBBS; FWACP; MPH ${ }^{1}$, Yunusa Edzu \\ $\mathrm{U}, \mathrm{MBBS}$; MPH; FWACP ${ }^{1}$
}

1- Consultant, Dept. of Community Medicine, Usmanu Danfodiyo University Teaching Hospital, Sokoto, Sokoto State, Nigeria. 2- Professor, Dept. of Community Medicine, Usmanu Danfodiyo University Teaching Hospital, Sokoto, Sokoto State, Nigeria.

\begin{abstract}
Received: January 2017, Accepted: July 2017

Background: Petrol station attendants are a high risk group and are exposed to occupational hazards with no control over the length and frequency of safety regulation. The study aimed to assess the knowledge of petrol station attendants about the occupational hazards they are exposed to and the safety practices used to prevent them.

Materials and Methods: The study was carried out in Sokoto metropolis, Nigeria and it was a descriptive cross-sectional study. Using a multi-staged sampling technique, 108 petrol station attendants were recruited for the study. Data was collected using a semi-structured questionnaire adapted from published articles which was administered to the respondents by an interviewer. The data was imputed and analyzed using SPSS software.

Results: Sixty-two $(59.0 \%)$ respondents had poor knowledge while only $16(15.1 \%)$ had negative attitude. Seventy-two $(72.4 \%)$ of respondents knew that volatile organic compounds (VOCs) were harmful to health and a good proportion knew about work safety practices such as they ought not to smoke cigarettes at the workplace $(92.4 \%)$. Only $2.8 \%$ of respondents used hand gloves while $19.4 \%$ used apron always.

Conclusions: The finding of poor knowledge of VOCs with very few of them adopting workplace safety practices underscores the need for employers in this sector to identify workplace hazards, adopt safety measures to curb them, train new employees and retrain staff on safety measures, and provide personal protective equipment (PPE) for daily use.
\end{abstract}

Keywords: Volatile Organic Compounds, Knowledge, Safety, Hazards

\section{Introduction}

Premium motor spirit (PMS) remains the only option used as fuel in the automobile industry in Nigeria without any viable alternative in sight. The love for automobiles leading to the acquisition of several thousands of it annually makes the sale of PMS thrive in Nigeria. PMS contains volatile organic compounds (VOCs) as solvents which can have detrimental effects on human health (1). VOCs such as benzene are limited by regulation to $6 \%-8 \%$ of the content of PMS in Nigeria and between $1 \%$ $(\mathrm{v} / \mathrm{v})$ to $5 \%$ in the USA and Europe (2-5). An estimated 7400 fires and explosions safety measures among the attendants occurred per year at public service stations in the United States of America from 1994 through 1998 (6). Of those 7400 fires, nearly two-thirds (4620) involved vehicles. Vehicle fires led to an annual average of one civilian death, 37 civilian injuries and costed $\$ 7.7$ million

\footnotetext{
* Corresponding author: Okafoagu Nneka Christina, Dept. of Community Medicine, Usmanu Danfodiyo University Teaching Hospital, Sokoto, Sokoto State, Nigeria.

E-mail: Stixveno4520@gmail.com
} 
damage in property (6). Petrol station attendants are a high-risk group and are directly exposed to VOCs with no control over the length and frequency of exposure despite safety regulations (7). These attendants are exposed to several occupational hazards which may limit their efficacy, efficiency and productivity. The safety of people and protection of the environment are major concerns at petrol filling stations. Petrol and other motor fuels are potentially hazardous at ambient temperatures and petrol gives off vapors which when mixed with air in appropriate proportions can burn with explosive force if ignited (8).

Safety practices depend on having good knowledge about danger and harmful effects of VOCs and safety measures put in place against them which will then translate to appropriate beliefs and attitude to the health risks associated with exposure to solvents ( 9 , 10). Therefore, there was the need for petrol station attendants to be made aware of these adverse effects. The study aimed to assess the knowledge and attitude towards occupational hazards and safety practices among petrol station attendant.

\section{Material and Methods}

The study was conducted in Sokoto metropolis in Sokoto State, Nigeria. Sokoto metropolis according to Edict 7 (1995), includes areas within $16 \mathrm{~km}$ radius from the race course; this therefore includes four Local Government Areas (LGA) of the state viz Sokoto North, Sokoto South, Dange-Shuni, and Wamakko Local Government Areas with total population of 937,471 . In the metropolis, a hundred petrol stations can be found with eighty being functional at the time of the study and each employing an average of three petrol attendants. The petrol stations belonged to the independent and non-independent marketers. The study was a descriptive cross-sectional design. The study population consisted of petrol station attendants working at petrol pumps in functional petrol stations in Sokoto metropolis. Petrol pump workers, men or women engaged in fuel filling for at least 6 months were eligible to participate in the study. Those who were working as petrol station cashier, cleaner, clerk and customer service representative or who were involved in replacement of vehicle oil were excluded from the study.

The level of significance was set at 5\% $(\alpha=$ $0.05)$. The power of the study was set at $80 \%=$ 0.8 . The sample size was determined by using the formula $\mathrm{n}=\mathrm{z}^{2} \mathrm{pq} / \mathrm{d}^{2}$. An estimated proportion of $94 \%$ was used for the variable of interest in the population (level of awareness of safety measures) (11). Therefore, 108 petrol station attendants were recruited for the study after correcting for attrition. A multi-stage sampling technique was used. Using a simple random sampling technique through balloting, ten petrol stations were selected each from the four metropolitan LGAs. All the petrol station attendants in the ten petrol stations (each in the 4 metropolitan LGA) were listed. Using a systematic sampling technique, the desired number of respondents were then selected.

A structured pretested intervieweradministered questionnaire was used to assess the knowledge, attitude and safety practices of workers towards occupational hazards. The instrument was adapted from published articles with some modifications (11-14). Ten research assistants comprising medical students from Usmanu Danfodiyo University Teaching Hospital, Sokoto, interviewed the respondents after they had been trained on the objectives of the study and survey instrument. Data processing was done using SPSS software (version 20.0, IBM Corporation, Armonk, NY, USA). Quantitative variables were summarized using range, mean and standard deviation. Categorical variables were summarized using frequencies and percentages. There were 10 questions which assessed knowledge and correct answers were scored one (1) and incorrect answers and those with no response were scored nil (0) and converted to percentages. Scores were then graded as good knowledge (> 50\%) and poor 
knowledge $(\leq 50 \%)$. The level of statistical significance $(\alpha)$ was set at $P<0.05$. Ethical approval for the study was sought from the Research and Ethics Committee of Usmanu Danfodiyo University Teaching Hospital. Permission was also obtained from the association of petrol station workers in Sokoto before the study was carried out. Informed consent was obtained from the study participants after explaining the purpose of the study and assurance of confidentiality.

\section{Results}

Majority of the respondents $67(63.8 \%)$ were in the age-range 20-29 and the mean age of the respondents was $29.15 \pm 4.76$ years. Only ten $(9.5 \%)$ respondents were women; fifty-two respondents $(49.5 \%)$ were single and most of the respondents $(\mathrm{n}=51,48.5 \%)$ had secondary level of education (Table 1).

Table 1: Sociodemographic characteristics of respondents

\begin{tabular}{|c|c|c|}
\hline & Variable & $\mathrm{n}=105(\%)$ \\
\hline \multirow{4}{*}{ Age (years) } & $20-29$ & $67(63.8)$ \\
\hline & $30-39$ & $32(30.5)$ \\
\hline & 40-49 & $6(5.4)$ \\
\hline & $\begin{array}{c}\text { Total, mean } \pm \text { standard } \\
\text { deviation }\end{array}$ & $29.15 \pm 4.76$ \\
\hline \multirow{2}{*}{ Sex } & Men & $95(90.5)$ \\
\hline & Women & $10(9.5)$ \\
\hline \multirow{3}{*}{$\begin{array}{c}\text { Marital } \\
\text { status }\end{array}$} & Single & $52(49.5)$ \\
\hline & Married & $52(49.5)$ \\
\hline & Separated & $1(1.0)$ \\
\hline \multirow{5}{*}{$\begin{array}{l}\text { Educational } \\
\text { status }\end{array}$} & Uneducated & $11(10.5)$ \\
\hline & Quaranic & $11(10.5)$ \\
\hline & Primary & $26(24.8)$ \\
\hline & Secondary & $51(48.5)$ \\
\hline & Tertiary & $6(5.7)$ \\
\hline
\end{tabular}

Sixty $(57.1 \%)$ of the respondents were temporarily employed and 98 (93.3\%) had worked for 10 years and below. Majority 81 (77.1\%) worked for 6-7 days in a week while $53(50.5 \%)$ worked for greater than 8 hours in a day.
Sixty-two (59.0\%) respondents had poor all round knowledge on occupational hazards seen in their workplace while 43 (40.9\%) had good knowledge. The mean knowledge score was found to be $48.21 \pm 21.05$ (Table 2).

Table 2: Respondents' knowledge of occupational hazards

\begin{tabular}{cc}
\hline Grading of knowledge score & $\mathbf{n = 1 0 5}(\boldsymbol{\%})$ \\
\hline$\leq 50 \%$ (poor knowledge) & $62(59.0)$ \\
\hline$>50 \%($ good knowledge) & $43(40.9)$ \\
\hline Mean \pm standard deviation & $48.21 \pm 21.05$
\end{tabular}

Seventy-six $(72.4 \%)$ of respondents knew that VOCs were harmful to health, $71.4 \%$ knew that they ought to use personal protective equipment (PPE) during their work shift, $80 \%$ knew workers needed to be given protective guidelines on VOCs (Table 3). 
Table 3: Respondents' attitude to workplace hazards

\begin{tabular}{ccc}
\hline \multirow{2}{*}{ Variables } & \multicolumn{2}{c}{$\mathbf{n = 1 0 5 ( \% )}$} \\
\cline { 2 - 3 } & Yes & No \\
\hline Exposure to VOCs is harmful to health & $76(72.4)$ & $29(27.6)$ \\
\hline Should workers have protective guidelines on VOCs & $84(80.0)$ & $21(20.0)$ \\
\hline Should workers use PPE during shift work & $75(71.4)$ & $30(28.6)$ \\
\hline Should workers be trained on using PPE & $60(57.1)$ & $45(42.9)$ \\
\hline Should workers wash hands during work shift & $83(79.0)$ & $22(21.0)$ \\
\hline Should workers not eat or drink in workplace & $58(55.2)$ & $47(44.8)$ \\
\hline
\end{tabular}

VOCs: Volatile organic compounds; PPE: Personal protective equipment

A good proportion observed work safety practices such as they ought not to smoke cigarettes at the workplace (92.4\%), wash, bath and change clothes immediately after work (81\%), no eating or drinking (46.7\%, Table 4). Only $2.8 \%$ of respondents used hand gloves and same proportion used boots always while $19.4 \%$ used apron always. None of the respondents neither used eye goggles nor respiratory mask always. Reasons for not using PPE included that the equipment were not available $(57.1 \%)$, workers not aware of them $(22.9 \%)$ and they cause discomfort (15.7\%).

Table 4: Respondents' work safety practices

\begin{tabular}{ccc} 
Variables & \multicolumn{2}{c}{$\mathbf{n = 1 0 5}(\mathbf{\%})$} \\
\cline { 2 - 3 } Work safety practices & Yes & No \\
\hline Wash hands before eating or drinking at work & $87(82.9)$ & $18(17.1)$ \\
\hline Wash, bath and change clothes after work & $85(81.0)$ & $20(19.0)$ \\
\hline Do not eat or drink while working & $49(46.7)$ & $56(53.3)$ \\
\hline Do not light a match or smoke close to VOCs & $97(92.4)$ & $8(7.6)$ \\
\hline Ensure car engines are switched off while dispensing VOCs & $83(79.0)$ & $22(21.0)$ \\
\hline Ensure good nozzle handling & $81(77.1)$ & $24(22.9)$ \\
\hline Do not answer cell phone while dispensing VOCs & $40(38.1)$ & $65(61.9)$ \\
\hline Use or wear PPE while dispensing VOCs & $36(34.3)$ & $69(65.7)$ \\
\hline
\end{tabular}

VOCs: Volatile organic compounds; PPE: Personal protective equipment

\section{Discussion}

The age of respondents ranged from 20 to 46 years with a mean of 29.15 years which is similar to a study in southern Brazil where respondents had an average age of 30.25 years (12). About $90.5 \%$ of respondents were men, this was not surprising considering that PSA is predominantly a male dominated occupation in Nigeria which is similar to findings in Ile-Ife where $72 \%$ of respondents were also men (11). Similarly the south Brazil study also showed that $90.5 \%$ of respondents were men (12). Our study showed same proportion of singles and married $(49.5 \%$ each $)$ while the south Brazilian study showed a slight preponderance of the single (52\%) compared to the married (43.9\%) (12). Our study also showed that $79 \%$ of respondents had at least some form of formal education while all respondents from a similar study in Ile-Ife had at least primary education (12). This may be explained by the fact that the primary school enrolment and completion rates are much higher in southern Nigeria where Ile-Ife is located compared to northern Nigeria where this study site is located. Only $6.7 \%$ of respondents have worked for more than 10 years at this occupation compared to $54 \%$ in a similar study in Thailand (13).

Only about $41 \%$ of respondents had good all round knowledge of occupational hazards present in the workplace. This is similar to a study in Thailand which found that only $34.1 \%$ had good knowledge towards hazards 
(13). The study also showed that the older respondents had better knowledge about these hazards compared to the younger respondents. This may largely be due to the fact that the older respondents were largely those who had worked for more than 10 years on the job. Although higher educational attainment did not lead to better knowledge of the workplace hazards among respondents, longer work experience appeared to.

A good proportion of respondents were aware of work safety practices such as the harmful effects of VOCs on health $(72.4 \%)$ and the need to use PPE while at work (71.4\%); however, only $19.4 \%$ of them had an apron, only $2.8 \%$ had hand gloves and boots while none had face mask or eye goggles. This finding is not too different from that seen in a study in Gaza strip where $14.3 \%$ of respondents wore overalls, $28.6 \%$ used gloves, $2.9 \%$ wore goggles, $9.5 \%$ used respiratory mask and $1.0 \%$ wore special boots (14). The main reason given for non-usage of PPE was their non-availability which differs from a study in Thailand where the feeling of discomfort and unease while wearing PPE was the main reason for non-usage (12). This brings to the fore the role of safety regulatory agencies before certification of PMS service stations.

\section{Conclusion}

These findings further highlight the severity of the risks associated with this profession and underscores the need for employers in this sector to identify workplace hazards, put up safety measures to curb them, train new employees and continuously do on the job training and retraining of staff on safety measures at the workplace and provide PPE for daily use.

\section{Acknowledgement}

The study acknowledges the executives of the association of Petrol marketers in Sokoto metropolis for their cooperation in conducting this study.
Conflict of interests: None declared.

\section{References}

1. Brautbar N, Williams J. Industrial solvents and liver toxicity: risk assessment, risk factors and mechanisms. Int J Hyg Environ Health 2002; 205(6):479-91.

2. Wallace L. Environmental exposure to benzene: an update. Environ Health Perspect 1996; 104(Suppl 6):1129-36.

3. Menkes DB, Fawcett JP. Too easily lead? Health effects of gasoline additives. Environ Health Perspect 1997; 105(3):270-3.

4. Brief RS, Lynch J, Bernath T, Scala RA. Benzene in the workplace. Am Ind Hyg Assoc J 1980; 41(9):616-23.

5. Guldberg PH. Gasoline and vapor exposures in service station and leaking underground storage tank scenarios. J Expo Anal Environ Epidemiol 1992; 2(1):97-107.

6. National Fire Protection Association's Special Data Information Package. Fires in or at Service Stations and Motor Vehicle Repair and Paint Shops [Internet]. 2016 [cited 2016 Nov 14]. Available from: http://www.nfpa.org/assets/files

7. Chiabhlaem T. Occupational Health and Safety (Thailand) [Internet]. 2011 [cited 2016 Dec 3]. Available from: http://thongchai99.wordpress.com

8. Health and Safety Executive. Dispensing Petrol: Assessing and controlling the risk of fire and explosion at sites where petrol is stored and dispensed [Internet]. 2002 [cited 2017 Feb 12]. Available from: http://www.hse.gov.uk/press.Assessed

9. Keretetse GS, Laubscher PJ, Du Plessis JL, Pretorius PJ, Van Der Westhuizen FH, Van Deventer E, et al. DNA damage and repair detected by the comet assay in lymphocytes of African petrol attendants: A pilot study. Ann Occup Hyg 52(7):653-62.

10. Wiwanitkit V. Classification of risk occupation for benzene exposure by urine trans-muconic acid level. Asian Pac J Cancer Prev 2006; 7(1):149-50.

11. Afolabi OT. Assessment of safety practices in filling stations in Ile-Ife; South-Western Nigeria. Journal of Community Medicine and Primary Health Care 2011; 23(1-2):9-15

12. Cezar-Vaz MR, Rocha LP, Bonow CA, da Silva MRS, Vaz JC, Cardoso LS. Risk perception and occupational accidents: A study of Gas station workers in Southern Brazil. Int J Environ Res Public Health 2012; 9(7):2362-77.

13. Langkulsen U, Vichit-Vadakan N, Taptagaporn S. Safety and health in the petrochemical 
industry in Map Ta Phut, Thailand. J Occup Health 2011; 53(5):384-92.

14. Lubbad AH, Al-Hindi AI, Hamad AAI, Yassin MM. Exposure of gasoline station workers to leaded gasoline in the Gaza strip: awareness and self-reported symptoms. Annals of Alquids Medicine 2010; 6:1-10 